\title{
Pengaruh Militer Dalam Sistem Politik Myanmar Terhadap Diskriminasi Etnis Rohingya Pada Tahun 2017
}

\author{
Hardi Alunaza SD ${ }^{1}$, Bastian Andhony Toy ${ }^{2}$ \\ ${ }^{1}$ Fakultas Ilmu Sosial dan Ilmu Politik, Universitas Tanjungpura, Indonesia \\ hardi.asd@fisip.untan.ac.id \\ ${ }^{2}$ Fakultas Ilmu Sosial dan Ilmu Politik, Universitas Tanjungpura, Indonesia, \\ bas.andhony@gmail.com
}

\begin{abstract}
ABSTRAK
Tulisan ini bertujuan untuk membahas sejauh mana pengaruh dari militer dalam sistem politik di Myanmar terkait kasus penindakan terhadap etnis Rohingya pada tahun 2017. Pemerintahan Myanmar melalui pihak militer dinilai menggunakan kekerasan dan diskriminasi terhadap etnis Rohingya sehingga menimbulkan ribuan korban jiwa dan membuat etnis Rohingya terusir serta berupaya mengungsi ke negara-negara tetangga. Penelitian ini dilakukan untuk menilai peran militer dalam sistem pemerintahan Myanmar karena berdasarkan Konstitusi tahun 2008, militer memiliki kursi sebesar 25 persen di parlemen Myanmar dan memiliki sejumlah kewenangan dalam sistem politik. Hal ini dapat dianggap sebagai pemicu dari agresivitas militer terhadap etnis Rohingya karena perwakilan militer yang memiliki eksistensi dalam parlemen Myanmar. Penulis menggunakan teori konkordansi dan konsep new professionalism of internal security and national development dalam menganalisis fenomena terkait. Hasil penelitian ini menunjukkan adanya pengaruh militer dalam pemerintahan Myanmar karena berdasarkan konstitusi, militer mengontrol tiga departemen strategis yaitu Pertahanan, Urusan Dalam Negeri, dan Perbatasan. Militer juga memegang kendali penuh atas angkatan bersenjata, kepolisian dan pasukan keamanan, sehingga menunjukkan adanya peran militer dalam kebijakan Myanmar terkait penindakan terhadap etnis minoritas Rohingya.
\end{abstract}

Kata Kunci: Militer, Sistem Politik, Diskriminasi

\begin{abstract}
This paper aims to discuss the extent to which the influence of the military in the political system in Myanmar related to cases of the 2017 prosecution of ethnic Rohingya. Myanmar's government through the military is considered using violence and discrimination against Rohingya ethnic groups resulting in thousands of casualties and the migration of ethnic Rohingya to neighboring countries. This research was conducted to assess the role of the military in the Myanmar government system because under the 2008 Constitution, the military occupied 25 percent seats of the Myanmar parliament and placed a number of authorities in the political system. The presence of military representatives in the Myanmar parliament can be considered as a trigger for the military's aggressiveness towards Rohingya to analyze the extends of military influence in Rohingya case. The author uses concordance theory and the concept of new professionalism of internal security and national development. The results of this research indicate the existence of military influence in the Myanmar government because under the constitution, the military controls three strategic departments, namely Defense, Internal Affairs and Border. The military also holds full control of the armed forces, police and security forces, thus demonstrating the military role in Myanmar's policies regarding prosecution of the ethnic minority of Rohingya.
\end{abstract}

Keywords: Military, Political System, Discrimination

\section{Pendahuluan}

Negara sebagai suatu kesatuan dari seluruh elemen masyarakat, wilayah teritorial, serta memiliki pemerintahan tentu memiliki tujuan untuk tetap menjaga keberlangsungan hidup negara dan kepentingan rakyat. Soultau 
menyatakan bahwa "negara adalah alat (agency) atau wewenang (authority) yang mengatur atau mengendalikan persoalanpersoalan bersama, atas nama masyarakat". Dengan kata lain, negara melalui pemerintah tentu memiliki kebijakan atau wewenang dalam mengatur dan menciptakan aturanaturan atau hukum dalam upaya menjaga eksistensi dari negara tersebut.

Dalam menjalankan suatu pemerintahan, tiap negara memiliki sistem politik yang menjadi landasan dan tujuan bagi tindakan yang dilakukan oleh pemerintahan terhadap fungsionalitas dan kehidupan dari negara tersebut. Dengan adanya sistem pemerintahan yang berjalan sesuai dengan konstitusi yang berlaku di negara tersebut, maka warga negara akan memiliki aturan dan hukum yang berlaku. Sistem politik juga menjadi cerminan budaya politik (political culture) dari suatu negara yang terdiri dari pandangan hidup, norma, dan pola-pola orientasi pada politik serta dipengaruhi oleh sejarah, status sosial, agama, konsep mengenai kekuasaan, kepemimpinan dan sebagainya. ${ }^{2}$

Sistem politik atau pemerintahan negara dapat terbagi dalam beberapa jenis, baik berbentuk demokrasi presidensial, demokrasi parlementer, otoritarian, dan sebagainya. Namun dalam suatu sistem pemerintahan, tidak hanya mengenai hubungan antara pemerintah dengan rakyat, tetapi juga adanya hubungan antara sipil dan militer. Dalam sistem demokrasi, Huntington menyatakan ada bentuk hubungan sipil-militer yang ideal yaitu "kontrol sipil obyektif" atas militer, di mana sipil memiliki supremasi atas militer tetapi memberikan profesionalisme militer untuk tetap independen terkait ruang lingkup militer. Terkait hubungan sipil-militer, Barany menyatakan bahwa "demokrasi tidak dapat dikonsolidasikan tanpa elit militer yang berkomitmen untuk pemerintahan demokratis dan taat kepada elit politik". Pemikiran Barany

${ }^{1}$ Miriam Budiardjo, Dasar-dasar Ilmu Politik (pp. 39). Jakarta: PT. Gramedia Pustaka Utama. 2001. ${ }^{2}$ Ibid, pp. 49. menekankan bahwa diperlukan ketaatan dari pihak militer untuk tetap terfokus terhadap profesionalismenya agar elit politik dapat mengendalikan militer sebagai alat pertahanan dan keamanan negara. ${ }^{3}$

Namun bagaimana ketika militer yang seharusnya mendapat pengawasan dan berada dalam kendali pihak sipil justru berupaya melakukan kudeta ataupun berupaya berperan dalam politik dengan dalih untuk menjaga konstitusi negara agar tetap berjalan atau mungkin menilai pihak sipil dianggap tidak mampu dalam menjalankan pemerintahan nasional. Hal ini terjadi di negara Myanmar, pernah terjadi transisi dari pemerintahan sipil ke pemerintahan militer, walaupun akhirnya tahun 2011 kembali kepada pemerintahan sipil namun militer tetap memiliki peran dalam sistem politik.

Myanmar merupakan salah satu negara di Asia Tenggara yang merdeka sejak tahun 1948. Pemerintahan Myanmar dibawah pimpinan $\mathrm{U} \mathrm{Nu}$ menerapkan sistem demokrasi parlementer dan dipimpin oleh seorang presiden sebagai kepala negara dan pemerintahan. Namun pada tanggal 2 Maret 1962, terjadi kudeta terhadap pemerintahan sipil $\mathrm{U} \mathrm{Nu}$ yang dilakukan pihak militer yang dipimpin oleh Jenderal $\mathrm{Ne}$ Win. Kudeta tersebut dilatarbelakangi kegagalan pemerintah sipil dalam menyelesaikan masalah dalam negeri, sebelumnya pihak militer telah memberikan ultimatum selama 2 tahun kepada pemerintah sipil terkait penyelesaian masalah di Myanmar. Keberhasilan kudeta oleh militer kemudian menjadi awal pemerintahan militer di Myamar dari tahun 1962 hingga 2011. ${ }^{4}$

Aung San Suu Kyi dan kelompok yang pro demokrasi sempat menentang rezim militer kemudian ditangkap oleh pemerintahan militer.

${ }^{3}$ Maung Aung Myoe, Emerging Pattern Of CivilMilitary Relations In Myanmar. Southeast Asian Affairs. 2017. Disandur dari https://www.researchgate.net

${ }^{4}$ Devi Apriyanti, Reformasi Politik dan Ekonomi di Myanmar Pada Masa Pemerintahan Presiden U Thein Sein (2011-2013). Jurnal Online Mahasiswa (JOM) Fisip 1, 2. 2014. Disandur dari https://jom.unri.ac.id. 
Namun, adanya tekanan dari dunia internasional, Aung San Suu Kyi akhirnya dibebaskan pada tahun 2010. Hal ini kemudian menjadi pertanda bagi demokratisasi di negara Myanmar. Pada Januari 2011, adanya upaya demokratisasi sejak kepemimpinan Thein Sein sebagai presiden Myanmar melalui pemilihan umum, di mana sebelumnya presiden dijabat oleh rezim militer Jenderal Than Shwe sejak tahun 1992. Presiden Thein Sein kemudian mengambil upaya transformasi politik dari militer ke sipil melalui pemilu untuk mendapatkan perwakilan rakyat agar duduk di kursi parlemen Myanmar. Hasil dari pemilu tersebut dimenangkan oleh partai oposisi National League Democracy (NLD) yang dipimpin oleh Aung San Suu Kyi. ${ }^{5}$

Namun, walaupun telah kembali dipimpin oleh pemerintahan sipil, berdasarkan Konstitusi 2008, militer tetap memiliki kewenangan dalam sistem pemerintahan melalui kepemilikan hak kursi di parlemen Myanmar sebesar 25 persen dan berhak mengontrol tiga kementrian yaitu pertahanan, urusan dalam negeri dan perbatasan. Panglima militer juga memiliki kesetaraan jabatan dengan wakil presiden. Ketika terjadi situasi darurat dan jika diperlukan maka panglima militer berhak menggantikan presiden dalam pengambilan keputusan terkait kedaulatan dan pertahanan nasional. $^{6}$

Pada tahun 2012, pemerintahan Thein Sein menjadi perhatian dunia ketika terjadi pembantaian terhadap etnis Rohingya yang dilatarbelakangi pembunuhan dan pemerkosaan terhadap Ma Thida Htwe, seorang gadis beragama Buddha di perkampungan Thabyechaung, Desa Kyauknimaw. Pelaku kejahatan tersebut adalah tiga orang pemuda Muslim dan dua

${ }^{5}$ Muslina, Upaya UNDP (United Nations Development Programme) Dalam Memajukan Demokrasi Di Myanmar. Jurnal Online Mahasiswa (JOM) FISIP 3, 2. 2016. Disandur dari https://jom.unri.ac.id.

${ }^{6}$ Moe Thuzar, Understanding Democracy, Security, and Change in Post-2015 Myanmar. The Journal of Asia Studies 22, 1. 2017. Disandur dari http://aas2.asian-studies.org. diantaranya adalah etnis Rohingya, yang kemudian telah ditangkap dan dipenjarakan oleh Kepolisian Myanmar. Akan tetapi, kerusuhan tetap terjadi karena warga desa tetap marah akibat perbuatan pelaku terlebih lagi pelaku merupakan etnis Rohingya. Pada bulan Juni 2012, konflik semakin memburuk yang dipicu pembakaran bus oleh etnis lokal Myanmar di Rakhine, kemudian menewaskan 10 orang Muslim Rohingya. Hal ini kemudian memicu kerusuhan rasial di Rakhine antara etnis lokal beragama Buddha dan Rohingya menjadi semakin meluas. ${ }^{7}$

Pertikaian antara rakyat Myanmar dan etnis minoritas Rohingya sebenarnya telah terjadi sejak sekitar tahun 1972, pada waktu itu terjadi kerusuhan karena perebutan ekonomi dan kebutuhan hidup. Pemerintah ketika itu dianggap lebih melindungi etnis Rakhine (Myanmar) daripada Rohingya. Pemerintah melakukan perampasan hak atas tanah, pengusiran, pelarangan pelaksanaan ibadah, dan sejumlah tindakan lainnya oleh pemerintah militer yang juga dibantu para biksu Rakhine untuk mengusir penduduk Rohingya. ${ }^{8}$

Pada tahun 1974, Pemerintahan Myanmar menyatakan bahwa Myanmar tidak memberikan kewarganegaraan kepada etnis Rohingya karena dianggap sebagai imigran ilegal dan pendatang dari Bangladesh. Hal ini menunjukkan bahwa pemerintah Myanmar tidak mengakui kewarganegaraan etnis Rohingya dan menilai bahkan sebelum kemerdekaan Myanmar sejak 1948, bahwa Rohingya bukanlah etnis yang telah menetap di Myanmar. Hal ini juga terkait kebijakan pemerintah Myanmar mengesahkan UU Kewarganegaraan tahun 1982, mengenai pembagian tiga kelompok warga negara yaitu kewarganegaraaan penuh, warna negara

${ }^{7}$ Tri Joko Waluyo, Konflik Tak Seimbang Etnis Rohingya dan Etnis Rakhine di Myanmar. Jurnal Transnasional 4, 2. 2013. Disandur dari https://ejournal.unri.ac.id.

${ }^{8}$ Alfi Revolusi, et.al, Faktor-faktor Penyebab Konflik Etnis Rakhine dan Rohingya di Myanmar Tahun 2012. Artikel Ilmiah Hasil Penelitian Mahasiswa Universitas Jember. 2013. Disandur dari http://repository.unej.ac.id. 
asosiasi dan penduduk naturalisasi. Sementara Rohingya tidak diakui kewarganegaraannya karena dianggap sebagai warga asing. ${ }^{9}$

Pada tanggal 25 Agustus 2017, kembali terjadi pembantaian terhadap etnis Rohingya yang disebabkan adanya serangan oleh pemberontak yaitu Tentara Pembebasan Rohingya Arakan (Arakan Rohingya Salvation Army/ARSA) terhadap sejumlah pos keamanan dan militer yang menewaskan 12 aparat keamanan Myanmar. Pasukan militer Myanmar (Tatmadaw) kemudian membalas serangan tersebut tetapi tidak hanya kepada militan ARSA, warga sipil Rohingya turut menjadi target penyerangan oleh militer Myanmar. Berdasarkan data Badan Pengungsi (UNHCR), per September 2017, konflik di Rakhine, Myanmar telah menimbulkan lebih dari 1.000 korban jiwa dan sekitar 313.000 penduduk Rohingya mengungsi ke Bangladesh. Banyaknya jumlah pengungsi disebabkan militer Myanmar juga melakukan pembakaran terhadap tempat tinggal penduduk Rohingya. ${ }^{10}$

Berdasarkan pembahasan yang telah dipaparkan di atas, maka penulis dalam hal ini bertujuan untuk membuat suatu gagasan dan analisa mengenai "bagaimana pengaruh militer dalam sistem politik di Myanmar terkait kasus diskriminasi dan kekerasan terhadap Etnis Rohingya pada tahun 2017?". Permasalahan dalam penelitian ini perlu dikaji karena dalam memahami suatu kontelasi konflik yang terdapat di suatu negara, maka perlu juga memahami kondisi dan sistem politik yang ada di negara tersebut. Hal ini bertujuan memberikan deskripsi dan pemahaman mengenai latar belakang tindakan dan keputusan negara dalam menangani konflik yang sedang terjadi.

\footnotetext{
${ }^{9}$ Jawahir Thontowi, Perlakuan Pemerintah Myanmar terhadap Minoritas Muslim Rohingya Perspektif Sejarah dan Hukum Internasional. Jurnal Pandecta 8, 1. 2013. Disandur dari http://journal.unnes.ac.id.

${ }^{10}$ Adirini Pujayanti, Indonesia dan Tragedi Kemanusiaan Rohingya. Majalah Info Singkat Hubungan Internasional 9, 17. 2017. Disandur dari www.puslit.dpr.go.id.
}

Tulisan ini terbagi menjadi dua poin penting dalam menjelaskan serta menganalisa pengaruh militer dalam sistem politik di Myanmar. Pertama, kedudukan militer dalam sistem pemerintahan di Myanmar. Kedua, tindakan dan dukungan terhadap militer terkait kasus kekerasan terhadap etnis Rohingya pada tahun 2017.

\section{Kajian Pustaka \\ Teori Konkordansi (concordance theory)}

Rebecca L. Schiff, memperkenalkan suatu model alternatif dalam menjelaskan hubungan sipil-militer, yang dikenal sebagai teori konkordansi. Menurut teori ini, adanya konkordansi atau kesepakatan antara pihak militer, elit politik dan warga negara mengenai peran dari angkatan bersenjata, komposisi perwira militer, proses pengambilan sistem politik, proses rekrutmen dan pola militer dengan tujuan mencegah intervensi militer kepada pemerintahan sipil. Meskipun dalam teori ini menyatakan bahwa dalam suatu keputusan atau kesepakatan belum tentu terbentuk secara demokratis. Berbeda dengan teori pemisahan, teori konkordansi lebih menekankan kepada kemitraan dan integrasi antara militer, elit politik dan warga negara melalui pengesahan konstitusi yang telah disepakati. ${ }^{11}$

Pada dasarnya teori ini menjelaskan terdapat kondisi spesifik yang menentukan peranan militer di ranah domestik baik di pemerintah dan masyarakat. Konkordansi yang terbentuk tidak harus berupa pemerintahan khusus, seperangkat institusi atau proses proses pengambilan keputusan. Namun terdapat perjanjian yang telah ditetapkan dalam undangundang, keputusan atau konstitusi. Teori ini menjelaskan bahwa intervensi militer dapat dicegah apabila adanya kerja sama antara elit politik dan warga negara dalam membentuk pemerintahan nasional. ${ }^{12}$

\footnotetext{
${ }^{11}$ Myoe, op.cit, pp. 260.

${ }^{12}$ Rebecca L. Schiff, The Military and Domestic Politics: A Concordance Theory of Civil-Military Relations (pp. 43). New York: Routledge. 2009.
} 
Teori konkordansi menilai elit politik, militer, dan warga negara sebagai mitra strategis. Militer dapat didefinisikan dengan sederhana, secara umum militer sebagai lembaga yang diakui oleh elit politik dan masyarakat sebagai institusi yang membela integrasi dan perbatasan suatu negara. Sementara elit politik sebagai perwakilan pemerintahan yang memiliki fungsi untuk menentukan bentuk konkordansi (kesepakatan) yang berlaku antara sipil dan militer, kemudian membutuhkan dukungan militer dalam mempertahankan kedudukan pemerintahan sipil. Sedangkan warga negara adalah pihak yang memiliki hak untuk memilih dan dianggap pihak yang bekerja sama dalam membantu dan melegitimasi kekuatan militer dan politik. Teori konkordansi pada dasarnya tidak menyatukan institusi sipil dan politik, karena menilai warga negara sebagai mitra penting yang berbeda dari elit politik dan militer. Oleh karena itu, konkordansi yang ada tidak hanya terfokus kepada kelembagaan tetapi juga menggabungkan antara unsur sipil atau masyarakat dalam mempengaruhi peran dan fungsi dari militer. ${ }^{13}$

Dengan kata lain, teori ini menjelaskan apabila terjadi kesepakatan yang telah disetujui oleh elit politik, militer dan warga negara maka akan tercipta suatu hubungan antara sipil dan militer dalam proses pengambilan keputusan terkait konstelasi politik dan pertahanan serta keamanan nasional. Teori ini lebih menekankan kepada sinergi antara sipil-militer dalam menjalankan pemerintahan secara bersama-sama. Sipil tetap memegang kendali sebagai pemimpin pemerintahan dan militer tetap memiliki peran dalam pemerintahan namun dengan kesepakatan yang telah diatur oleh konstitusi di suatu negara. Akan tetapi, tidak dapat dipungkiri bahwa pembagian kekuasaan antara sipil-militer terkadang tidak demokratis karena terdapat kondisi kelembagaan dan budaya yang dimiliki oleh masing-masing pihak sehingga belum tentu mengarah kepada tipe hubungan yang ideal.

\footnotetext{
${ }^{13}$ Ibid.
}

\section{Konsep New Profesionalism of Internal Security and National Development}

Konsep ini diperkenalkan oleh Alfred Stepan, yang menilai bahwa ada reformasi terhadap profesionalisme militer dalam hal keamanan internal dan pembangunan nasional. Militer juga dituntut peduli terkait masalahmasalah politik dibandingkan hanya terfokus pada ancaman dari luar sehingga mengindikasikan militer dapat berafiliasi kedalam bidang-bidang politik. Namun, ekspansi dari militer ke dalam ranah politik dipengaruhi oleh sistem politik yang diterapkan oleh suatu negara. Ketika legitimasi pemerintahan sipil dinilai semakin lemah, maka kecenderungan militer terlibat dalam proses pembangunan nasional akan semakin besar. Profesi militer yang baru ini, lebih menekankan pada fungsi memperkokoh keamanan internal dan pembangunan nasional sesuai dengan wawasannya melalui doktrin militer dan pendidikan militer yang mumpuni. ${ }^{14}$

Berbeda dengan konsep Huntington mengenai otonomi militer yang menuntut militer terlepas dari politik, konsep new professionalism menilai perlu adanya koordinasi yang sinergis antara pemerintah sipil dan militer, di mana militer dilibatkan dan diberikan otoritas dalam menghadapi masalah keamanan nasional baik internal maupun eksternal yang berhubungan dalam aspek politik, ekonomi, dan urusan militer. Profesi militer diharapkan juga memiliki wawasan yang cukup dalam menangani masalah nasional dan menjadi bagian dalam proses pembangunan nasional negara. Profesionalisme militer dalam bidang politik saat ini masih berlaku di beberapa negara di Amerika Latin seperti Brasil, El Savador, dan Uruguay. Meskipun tidak terlibat politik secara langsung tetapi militer memiliki sejumlah hak yang mempengaruhi keputusan dari pemerintahan sipil, namun lebih ditekankan

${ }^{14}$ J. Kristiadi, Profesionalisme TNI di Tengah Transisi Politik. Jurnal Antropologi Universitas Indonesia. 2001. Disandur dari http://journal.ui.ac.id. 
pada keputusan yang terkait keamanan internal negara. ${ }^{15}$

Dengan demikian, konsep ini menyatakan bahwa adanya pembaharuan terhadap ruang lingkup profesi dari militer, di mana ketika Huntington menilai profesionalisme militer ditunjukkan melalui fokus terhadap bidang-bidang militer. Akan tetapi, menurut Stepan melalui konsep new professionalism menyatakan bahwa militer perlu dilibatkan lebih jauh dalam hal keamanan internal dan pembangunan nasional, secara langsung maupun tidak langsung perlu adanya keterlibatan militer dalam sistem politik negara tersebut. Pihak militer dianggap memiliki peran dan wawasan terhadap politik, ekonomi, serta urusan militer di dalam pemerintahan agar dapat mengawasi stabilitas keamanan internal dan membantu pelaksanaan pembangunan nasional sesuai dengan konstitusi dan tujuan negara.

\section{Metode Penelitian}

Penulis menggunakan metode kualitatif dengan pendekatan deskriptif, di mana penulis memberikan gambaran terkait situasi fenomena sosial, memilah informasi yang relevan dengan permasalahan yang ada baik dari sudut pandang teoritis maupun praktis. Selanjutnya dilakukan interpretasi data untuk dapat menjelaskan dan menganalisa permasalahan, serta memberikan jawaban terhadap bagaimana pengaruh militer dalam sistem politik Myanmar terkait kasus kekerasan terhadap etnis Rohingya pada tahun $2017 .^{16}$

Teknik pengumpulan data sekunder dalam penelitian ini diperoleh melalui studi kepustakaan dari buku, jurnal, skripsi, website dan literatur lainnya yang berhubungan dengan penelitian ini. Penulis menggunakan teknis

\footnotetext{
${ }^{15}$ John Richard Berg, (2016). Insurgents to Presidents: Contemporary Civil-Military Relations in Brazil, El Salvador, and Uruguay. Thesis, Monterey, California: Naval Postgraduate School. Disandur dari https://calhoun.nps.edu.

${ }^{16}$ J.R. Raco, Metode Penelitian Kualitatif - Jenis, Karakteristik, dan Keunggulannya (pp. 7). Jakarta: PT. Gramedia Widiasarana Indonesia. 2010.
}

analisis data kualitatif yang bersifat induktif, yaitu analisa melalui data yang telah diperoleh. Dalam penelitian ini, penulis menetapkan limitasi materi dan tahun yaitu mengenai kedudukan militer dalam sistem pemerintahan Myanmar dan tindakan serta dukungan terhadap militer terhadap etnis Rohingya tahun 2017.

\section{Kedudukan Militer dalam Sistem Pemerintahan Myanmar}

Berlakunya Konstitusi tahun 2008 serta terjadinya pemilihan umum tahun 2010 dan tahun 2015, menunjukkan Myanmar telah mengalami proses dalam transisi politik yang sebelumnya dipimpin pemerintahan militer oleh Tatmadaw (angkatan bersenjata Myanmar) selama 50 tahun, menjadi lebih demokratis dengan dipimpin kembali oleh pemerintahan sipil. Saat ini, presiden Myanmar adalah Htin Kyaw, yang berasal dari partai National League Democracy (NLD) sebagai pemenang pemilu pada tahun 2015. Kekuasaan legislatif di Myanmar menganut sistem bikameral, dipegang oleh Pyithu Hluttaw (Dewan Perwakilan) yang terdiri dari 440 kursi dan Amyotha Hluttaw (Majelis Nasional) terdiri dari 224 kursi. $^{17}$

Berdasarkan pasal 109(b) dalam Kontitusi 2008, menyatakan bahwa militer memiliki 110 kursi dalam Pyithu Hluttaw dan pasal 141(b) menyatakan militer memiliki 56 kursi di Amyotha Hluttaw. Hal ini menunjukkan dari total 664 jumlah kursi di parlemen, sebesar 166 kursi (25 persen dari total kursi) diperoleh oleh pihak militer. Anggota militer yang menduduki parlemen dipilih langsung oleh Panglima Tertinggi Tatmadaw. Pasal 436 menyatakan bahwa dalam pengesahan suatu amandemen konstitusi maka diwajibkan mendapat persetujuan sebesar 75 persen di parlemen, hal ini membuat Tatmadaw secara langsung memiliki hak veto terkait perubahan struktural ataupun

\footnotetext{
${ }^{17}$ Myoe, op.cit, pp. 259-263.
} 
menolak rancangan undang-undang dalam politik Myanmar. $^{18}$

Tatmadaw bertugas dan dipercaya untuk menjaga konstitusi agar tetap berjalan bahkan tidak mendapatkan pengawasan dari pihak sipil. Pemimpin Tatmadaw yaitu Panglima Tertinggi di militer juga diberikan hak konstitusional dalam mengambil alih pemerintah jika diperlukan. Hal ini telah diatur melalui Konstitusi 2008 pasal 40(c) bahwa ketika terjadi disintegrasi nasional dan hilangnya kekuasaan kedaulatan pemerintah sipil akibat pemberontakan, kekerasan dan sebagainya maka Panglima Tertinggi dari Kementrian Pertahanan atau NDSC (National Defence and Security Council) memiliki hak untuk mengambil alih dan melaksanakan kekuasaan negara. ${ }^{19}$

Meskipun telah dipimpin oleh pemerintah sipil, akan tetapi Panglima Tertinggi dan Tatmadaw memiliki otonomi serta peran penting baik di pemerintahan maupun legislatif. Berdasarkan Konstitusi 2008, Panglima Tertinggi memang setara dengan Wakil Presiden, namun ia menjadi otoritas tertinggi dari pertahanan dan keamanan nasional. Panglima juga adalah komandan tertinggi dari seluruh angkatan bersenjata, kepolisian, organisasi paramiliter, bahkan dapat memobilisasi sipil terkait pertahanan nasional bila diperlukan. ${ }^{20}$

Konstitusi 2008 juga memberikan kewenangan yang masif kepada Tatmadaw untuk independen mengenai kelembagaan militer. Pasal 20(b) memberikan Kementrian Pertahanan (NDSC) untuk secara mandiri mengatur semua urusan angkatan bersenjata. Berdasarkan pasal 232(b) dan 234(b), Panglima Tertinggi berhak memilih personil militer untuk menjabat pimpinan dan staf di tiga kementrian yaitu pertahanan, dalam negeri dan bidang hubungan perbatasan. Presiden

\footnotetext{
${ }^{18}$ Renaud Egreteau, Parliamentary Development in Myanmar - An Overview of the Union Parliament, 2011-2016 (pp. 24). Yangon: The Asia Foundation, hlm. 24. 2017. Disandur dari https://reliebweb.int. ${ }^{19}$ Myoe, op.cit, pp. 261.

${ }^{20}$ Ibid.
}

Myanmar juga tidak memiliki kekuatan setara dengan panglima militer karena pasal 342 menyatakan bahwa Presiden bukanlah panglima militer, tetapi adalah seseorang yang harus diusulkan dan disetujui oleh NDSC. ${ }^{21}$

Tatmadaw juga diberikan hak untuk mengatur dan mengadili seluruh permasalahan terkait angkatan bersenjata di Myanmar. Keputusan dari Panglima Tertinggi Tatmadaw adalah final dan konklusif, walaupun belum dibahas dalam pengadilan militer. Pemerintahan sipil tidak mendapat kewenangan untuk mengintervensi struktur, alokasi keuangan, dan tidak bebas mengawasi bisnis terkait militer. Pemerintah sipil dilarang untuk ikut campur dalam promosi atau pengangkatan personil militer. Tatmadaw juga memiliki hak eksklusif dalam membuat kebijakan dan melaksanakan agenda pertahanan nasional. ${ }^{22}$

\section{Tindakan dan Dukungan Militer Myanmar Terkait Diskriminasi Kepada Etnis Rohingya Tahun 2017}

Sejak bulan Agustus 2016, Aung San Suu Kyi sebagai Penasihat Negara (State Counsellor) dan Menteri Luar Negeri Myanmar membentuk suatu komisi penasihat (Komisi Pendampingan Wilayah Rakhine) terkait penyelesaian kasus Rohingya yang dipimpin oleh mantan Sekretaris Jenderal PBB, Kofi Annan. Komisi ini diberi masa kerja setahun dan telah menyampaikan hasil laporan pada Agustus 2017. Komisi tersebut menilai bahwa terjadi pelanggaran HAM, krisis pembangunan dan kemiskinan di Rakhine, Myanmar. Pemerintah Myanmar disarankan agar lebih selektif dan tidak agresif dalam menyikapi pemberontakan ARSA agar tidak meluasnya tindakan radikalisme yang dapat memperparah konflik di Rakhine, Myanmar. Akan tetapi, rekomendasi dari komisi tersebut tidak dilaksanakan pemerintahan Myanmar

\footnotetext{
${ }^{21}$ Kristian Stokke, Roman Vakulchuk, dan Indra Øverland, Myanmar: A Political Economy Analysis. Oslo: Norwegian Institute of International Affairs. 2018. Disandur dari www.nupi.no.

${ }^{22}$ Myoe, op.cit, pp. 261-262.
} 
karena terjadinya unjuk rasa besar-besaran di kota Yangoon, ibukota Myanmar, yang mana rakyat Myanmar meminta tindakan tegas dari pemerintah terhadap terorisme ARSA yang berasal dari kalangan Rohingya. ${ }^{23}$

Aung Sang Suu Kyi yang juga sebagai peraih nobel perdamaian dinilai gagal untuk menerapkan rekonsiliasi terhadap minoritas di Myanmar. Rekonsiliasi yang diartikan Aung San Suu Kyi hanya terfokus kepada partai politiknya dengan pihak militer sehingga menunjukkan sikap beliau dinilai masih terpengaruh oleh militer dalam politik Myanmar. Sejumlah inisiatif pemerintah Myanmar juga tidak terlaksana karena perlawanan dari elemen militer. Lembaga internasional juga tidak mampu menghentikan kekerasan karena belum terbentuk reformasi sektor keamanan karena dominasi yang kuat dari Tatmadaw dalam kehidupan sosial dan politik di Myanmar. ${ }^{24}$

Saat ini, baik pemerintah sipil dan pasukan militer tetap sejalan dalam kebijakan mereka terhadap etnis Rohingya. Aung San Suu Kyi disinyalir telah mendukung angkatan bersenjata Myanmar untuk melakukan serangan bersenjata mereka di daerah-daerah yang didominasi oleh Rohingya, sehingga tidak mengakui kejahatan dan kekerasan yang dilakukan oleh militer Myanmar. Pada 19 September 2017, dalam pidato nasional di Yangon, yang bertujuan untuk menenangkan kemarahan publik internasional, Aung San Suu Kyi mengklaim bahwa tidak begitu mengetahui secara jelas mengapa eksodus dari Rakhine tetap berlangsung, pernyataan ini dinilai banyak pihak bahwa pemerintah melindungi militer dari pemeriksaan atau investigasi. ${ }^{25}$

Pimpinan militer Myanmar dinilai tetap bebas dari pengawasan dari pemerintah sipil yang bahkan dipimpin oleh Aung San Suu Kyi sekalipun. Aaron Connelly, peneliti Asia Timur di Lowy Institute di Sydney mengatakan

\footnotetext{
${ }^{23}$ Pujayanti, op.cit, pp. 6.

${ }^{24}$ Ibid.

${ }^{25}$ Amnesty Internasional, Myanmar: Aung San Suu Kyi 'burying her head in the sand' about Rakhine Horrors. 2017. Disandur dari www.amnesty.org.
}

bahwa berdasarkan dari konstitusi tahun 2008, Panglima tertinggi militer Myanmar adalah pimpinan dari negara itu, karena dia tidak perlu melapor kepada Aung San Suu Kyi, bahkan tidak dapat dipecat oleh presiden Myanmar sekalipun. ${ }^{26}$ Hal ini kembali menegaskan bahwa pimpinan militer memiliki otoritas yang cukup kuat dalam pemerintahan Myanmar.

Salah satu biksu terkemuka Myanmar, Aswin Wirathu, sebagai pemimpin kelompok Buddha Ma Ba Tha yang cukup terkenal karena mendapat reputasi terhadap kebenciannya terhadap Islam dengan menentang kaum Rohingya dan Muslim. Wirathu telah mengajukan dan menuntut penutupan bisnis Muslim di negara tersebut dan telah mengajukan proposal kepada pemerintah dalam mencegah wanita Buddha untuk menikahi pria Muslim. Kelompok ini juga mengklaim sebagai gerakan mereka telah mendukung oleh pihak militer untuk menyingkirkan Rohingya dari Rakhine.

Pada 30 Agustus 2017, Wirathu mengatakan kepada para pengunjuk rasa yang menentang Rohingya di ibukota Yangon, bahwa hanya panglima militer yang dapat melindungi kehidupan dan properti penduduk Myanmar serta militer adalah satu-satunya yang dapat memberikan sebuah tindakan untuk membasmi teroris Muslim Bengali (Rohingya). Bahkan Wirathu juga tidak mempercayai bila terjadi pelanggaran militer seperti halnya pemerkosaan terhadap etnis Rohingya, karena ia menilai bahkan tubuh etnis Rohingya tidak pantas untuk diperkosa. Hal ini menunjukkan bahwa sikap militer tidak hanya didukung pemerintah, bahkan pimpinan agama di Myanmar mendukung penuh tindakan militer dalam memberantas etnis Rohingya. ${ }^{27}$

Pada bulan Maret 2017, Panglima Tertinggi Myanmar, Min Aung Hlaing menyatakan "Kami telah memberi tahu dunia

\footnotetext{
${ }^{26}$ Usaid Siddiqui, The Rohingya: The Latest Massacre in a Violence-Filled History. Al Jazeera Centre for Studies. 2017. Disandur dari http://studies.aljazeera.net. ${ }^{27} \mathrm{Ibid}$.
} 
bahwa kami tidak memiliki Rohingya di negara kami... Orang Bengali di negara bagian Rakhine bukan warga negara Myanmar dan mereka hanya orang-orang yang datang dan tinggal di negara ini". ${ }^{28}$ Bahkan Jenderal Hlaing selalu menentang setiap pembicaraan mengenai etnis Rohingya yang dapat diberikan kewarganegaraan dengan memperjelas keputusan militer terhadap konflik dan tetap melanjutkan operasi militer terhadap etnis Rohingya di provinsi Rakhine. ${ }^{29}$

Dalam laporan Amnesty Internasional (2017), sejumlah kementerian dan departemen pemerintah Myanmar yang dinilai bertanggung jawab terkait pelanggaran HAM terhadap Rohingya atau tidak mampu mencegah pelanggaran tersebut ternyata tidak berada dibawah pemerintahan otoritas sipil, namun justru dikendalikan oleh otoritas militer. Kepolisian, polisi penjaga batas, Departemen Administrasi Umum (The General Administration Department/GAD), serta angkatan bersenjata secara penuh dibawah kendali panglima angkatan bersenjata dan bukan di kontrol oleh pemerintahan sipil karena berdasarkan konstitusi, pemerintahan sipil tidak memiliki kuasa atas angkatan bersenjata. Terlebih lagi, pihak keamanan bukan berupaya menangkap para terduga anggota kelompok teroris, tetapi menggunakan dalih ancaman serangan dari teroris ARSA untuk sengaja melakukan penyerangan dan penindakan terhadap warga Rohingya. ${ }^{30}$

Sejak akhir bulan Agustus 2017, sekitar 480.000 pengungsi Rohingya dilaporkan telah melarikan diri ke Bangladesh akibat kekerasan di Rakhine. Amnesty International memberikan bukti bahwa ada upaya pihak militer Myanmar untuk mendorong kelompok Rohingya pergi dari wilayah Myanmar di dekat

\footnotetext{
${ }^{28}$ RFA (Radio Free Asia), (2017). Myanmar Military Chief Defends Crackdown Against Rohingya in Rakhine State. Disandur dari www.rfa.org.

${ }^{29}$ Ibid.

${ }^{30}$ Amnesty Internasional, (2017). Terpenjara Tanpa Atap": Apartheid Di Negara Bagian Rakhine Di Myanmar. Disandur dari https://www.amnesty.org.
}

perbatasan dengan Bangladesh. Berdasarkan laporan Yanghee Lee, Staf Khusus PBB untuk Hak Asasi Manusia di Myanmar dari awal tahun hingga September 2017, kekerasan terhadap etnis Rohingya telah menewaskan kurang lebih 1000 orang termasuk anak-anak dan bayi. ${ }^{31}$

Pihak Militer juga melakukan operasi untuk meletakkan ranjau darat di berbagai titik di dekat perbatasan Myanmar dengan Bangladesh. Hal ini menunjukkan pemerintah Myanmar dinilai berupaya menghalangi para pengungsi Rohingya untuk kembali dari Bangladesh. Pemerintah Myanmar sendiri juga belum meratifikasi sejumlah perjanjian hukum internasional. Ketika terjadi kekerasan oleh militer Myanmar sejak 2016 hingga Agustus 2017, sejumlah organisasi hak manusia telah mengecam kejahatan kemanusiaan dan perang yang dilakukan oleh pihak militer. ${ }^{32}$

PBB juga mengonfirmasi melalui citra satelit, bahwa sekitar 288 desa di Rakhine telah hancur dan dibakar. Pembakaran desa dilakukan oleh serangan terorganisir pada Muslim Rohingya dipimpin oleh kelompok nasionalis di Rakhine yang dihasut oleh para biksu Budha dan terkadang didukung pula oleh pasukan keamanan Myanmar. Dewan HAM di Jenewa, Zeidra'ad al Alhussein menilai bahwa mengecam operasi keamanan yang dinilai brutal terhadap etnis minoritas muslim di Rakhine. Sementara menurut Menteri Luar Negeri Bangladesh, Abulhasan Ali, menyatakan aksi dari militer Myanmar merupakan genosida, dan masyarakat internasional juga dapat menilai hal tersebut. Sekretaris Jenderal PBB, Antonio Guterres menyebutkan bahwa situasi pengungsi Rohingya telah darurat dan seharusnya tidak

\footnotetext{
${ }^{31}$ Md. Salman Sohel, The Rohingya Crisis in Myanmar: Origin and Emergence. Saudi Journal of Humanities and Social Sciences 2, 11A. 2017. Disandur dari http://scholarsmepub.com.

${ }^{32}$ Laura Baron Mendoza, (2017). The War Report 2017 - Myanmar: A Battle For Recognition. Research of Geneva Academy, Academy of International Humanitarian Law and Human Rights. Disandur dari https://www.genevaacademy.ch.
} 
dapat diterima karena jelas bahwa adanya upaya pembersihan etnis terhadap etnis Muslim Rohingya di Myanmar yang rakyatnya mayoritas beragama Buddha. ${ }^{33}$

Pihak keamanan Myanmar juga menutupi kekerasan terhadap etnis Rohingya di Myanmar dengan menangkap dan menahan reporter yang meliput tindakan militer. Pada Desember 2017, dua wartawan Reuters dituduh menerima informasi terkait dugaan kasus kekerasaan militer terhadap Rohingya. Pihak Myanmar menahan mereka berdasarkan Official Secrets Act (Undang-undang Rahasia Resmi Negara). Pengadilan telah menetapkan sidang terhadap reporter tersebut pada tanggal 10 Januari 2018. Hal ini menunjukkan militer memegang kendali dalam kasus Rohingya bahkan media massa diperlakukan sebagai tindakan kriminal bila dianggap mendiskreditkan militer dalam kasus ini. ${ }^{34}$

\section{Analisa Pengaruh Militer dalam Sistem Politik Myanmar Terhadap Kasus Etnis Rohingya Pada Tahun 2017}

Pasca kembalinya pemerintahan sipil dalam memegang kekuasaan tertinggi di Myanmar menunjukkan adanya upaya untuk menerapkan kembali sistem demokrasi di negara ini setelah beberapa dekade sebelumnya di kuasai oleh pemerintahan militer. Akan tetapi, sebelum peralihan pemerintahan dari militer ke sipil pada tahun 2010, telah di tetapkan Konstitusi tahun 2008 yang tidak hanya mengatur struktur politik di pemerintahan sipil, tetapi juga menjadi suatu dasar kesepakatan antara sipil dan militer terkait pembagian kekuasaan. Hal ini tentu sesuai dengan teori konkordansi di mana adanya upaya melalui elit politik, militer dan warga negara (diwakili oleh parlemen) untuk menetapkan konstitusi yang telah di sepakati bersama dan kembali menerapkan pemerintahan demokratis di negara Myanmar.

\footnotetext{
${ }^{33}$ Sohel, op.cit, pp. 1016.

${ }^{34}$ Jon Lunn \& Daniel Harari, Burma: Januari 2018 Update. Briefing Paper, No. 7901, 9. Januari 2018. Disandur dari http://www.parliament.uk/commonslibrary.
}

Meskipun begitu, terdapat sejumlah pasal kontroversial dalam konstitusi tersebut di mana militer menguasai penuh aspek-aspek terkait keamanan dan pertahanan nasional. Panglima Tertinggi militer juga sebagai pihak yang berdaulat atas seluruh angkatan bersenjata, ketimbang presiden yang justru tidak memiliki otoritas penuh dalam mengontrol militer. Pihak militer juga diberikan hak kursi di parlemen sebesar 25 persen, di mana hal ini membuat militer memiliki hak veto untuk menolak undangundang yang dianggap tidak sejalan dengan kepentingan mereka.

Selain itu, militer juga dapat mengontrol tiga kementrian yaitu pertahanan, urusan dalam negeri dan hubungan perbatasan. Hal ini menunjukkan adanya otoritas yang cukup mumpuni dari militer dalam menetapkan kebijakan operasi militer dengan dalih untuk menjaga keamanan dan pertahanan negara. Akan tetapi, Konstitusi 2008 juga tetap memberi sipil dalam memimpin pemerintahan, sehingga sipil mengontrol kebijakan pemerintahan sementara militer mengontrol bidang pertahanan. Dalam hal ini tentu dibutuhkan kesepahaman dari dua belah pihak dalam mencapai kepentingan serta saling berkoordinasi terkait pengambilan keputusan terhadap eksistensi negara Myanmar.

Profesionalisme militer dalam Myanmar telah ditunjukkan tidak hanya melalui legitimasi yang kuat terhadap urusan militer. Namun militer telah memiliki ruang lingkup dalam sistem politik melalui sejumlah kewenangan di kementrian lainnya seperti urusan dalam negeri dan perbatasan. Kebijakan ataupun rancangan undang-undang yang di rumuskan dalam parlemen dapat ditolak oleh militer apabila kontradiktif dengan kepentingan yang dimiliki pihak militer. Hal ini menunjukkan adanya profesionalisme baru dari pihak militer Myanmar dari sebelumnya hanya terfokus kepada keamanan dan pertahanan negara tetapi turut pula mengambil bagian dalam politik Myanmar.

Pihak militer juga memiliki profesionalisme dalam bidang ekonomi yang 
telah dijabarkan dalam pembahasan, bahwa mereka memiliki otonomi terhadap keuangan yang dialokasikan kepada mereka. Dalam hal ini militer berhak membentuk agenda sendiri baik dalam proses rekrutmen militer, pengadaan perlengkapan militer serta bisnis lainnya yang berhubungan dengan akomodasi militer. Hal ini menunjukkan bahwa militer Myanmar memiliki profesionalisme dalam mengatur perekonomian yang menyangkut alat keamanan dan pertahanan negara sehingga mereka tidak bergantung kepada pemerintahan sipil. Prinsip ini telah sesuai dengan konsep new professionalism of internal security and national development oleh Alfred Stepan, di mana penulis menilai bahwa militer telah memiliki pertimbangan tersendiri untuk menggunakan alokasi keuangan terhadap kebutuhan yang diperlukan oleh militer dan juga memiliki kepentingan tersendiri dalam perumusan undang-undang serta terlibat dalam beberapa kementrian strategis di Myanmar.

Pihak militer yang notabene adalah pemegang departemen pertahanan juga menggunakan dalih ancaman terorisme untuk menyerang kaum Rohingya, baik militan ARSA ataupun warga sipil etnis Rohingya. Selain karena ingin mempertahankan kepentingan nasional terkait keamanan dan pertahanan. Penyerangan militer dapat diindikasikan juga sebagai cara pemerintah dalam mengusir dan melenyapkan etnis Rohingya dari wilayah Myanmar. Hal ini jelas dilakukan karena sejak kemerdekaan Myanmar, pemerintah Myanmar tidak menggagap Rohingya bagian dari etnis di Myanmar.

Militer juga tidak berupaya menangkap oknum pelaku teroris tetapi juga melakukan kekerasan terhadap warga sipil karena menganggap Rohingya adalah ancaman nasional terlebih lagi adanya gerakan ARSA. Pemerintah sebagai pemimpin negara dan militer sebagai pertahanan negara, dalam hal ini terlihat saling mendukung terutama terkait penindakan terhadap etnis Rohingya. Bila pemerintah sipil tidak tegas kepada Rohingya, maka militer tetap akan menggunakan kekuatannya dalam menindak etnis Rohingya karena militer memiliki otonomi khusus terkait bidang pertahanan sehingga dapat membentuk dirinya sendiri dan memiliki dalih operasi militer untuk melindungi kepentingan negara. Dengan pengaruh militer yang cukup kuat di politik Myanmar, maka pemerintah Myanmar juga tidak dapat bertindak secara penuh karena hal ini telah diatur dalam Konstitusi 2008, militer juga akan melakukan intervensi bilamana keputusan pemerintah dinilai tidak efektif dalam upaya menjaga keamanan nasional.

\section{Kesimpulan}

Pemerintah sipil dalam suatu sistem demokrasi idealnya memiliki otoritas tertinggi dalam bidang politik suatu negara. Akan tetapi, lain halnya yang terjadi di Myanmar. Di mana adanya pengaruh militer dalam sistem politik sehingga pihak militer turut serta dalam proses pengambilan keputusan, sepatutnya militer terfokus pada pertahanan nasional. Hal ini ternyata telah diatur dalam konstitusi yang berlaku sehingga dalam berperan dalam politik, militer telah memiliki pegangan hukum dalam tiap kepentingan yang ingin dicapai melalui pemerintahan. Adanya kepemilikan sejumlah kursi di parlemen, mengontrol beberapa kementrian strategis, serta sebagai lembaga otonom dalam pertahanan negara, membuat militer menjadi aktor politik yang berpengaruh dalam kebijakan Myanmar.

Hal ini juga terlihat di mana militer melakukan agresi berlebihan terhadap etnis Rohingya. Walaupun mendapat tekanan dari masyarakat internasional, tetapi hal itu tidak cukup untuk menghentikan operasi militer karena telah di atur dalam konstitusi, bahwa militer berwenang penuh terhadap angkatan bersenjata dan sebagai penjaga kedaulatan negara. Militer bahkan tidak segan untuk menembak langsung warga sipil Rohingya tanpa melihat usia, gender, dan apapun situasinya saat itu. Sehingga secara langsung pemerintah Myanmar membiarkan militer dalam melakukan kekerasan ataupun 
diskriminasi, dengan dalih mempertahankan kedaulatan nasional.

Saran yang dapat disampaikan oleh penulis adalah perlunya keseriusan oleh pemerintah Myanmar dalam mengontrol perilaku militer baik melalui lobby ataupun pendekatan politik lainnya agar tidak menambah stigma buruk terhadap negara Myanmar. Meskipun dalam konteks memerangi terorisme, tetapi tidak perlu adanya operasi militer yang berlebihan karena hanya akan menambah korban jiwa dan meningkatkan eskalasi konflik di Myanmar. Pemerintah dan militer Myanmar diharapkan memiliki komitmen dalam menangkap pelaku terorisme ARSA, namun tidak melakukan generalisasi terhadap seluruh etnis Rohingya sebagai ancaman nasional.

\section{Daftar Pustaka}

Amnesty Internasional. (2017). Myanmar: Aung San Suu Kyi 'burying her head in the sand' about Rakhine Horrors. www.amnesty.org, [Diakses pada 28 Maret 2018].

Amnesty Internasional. (2017). "Terpenjara Tanpa Atap": Apartheid Di Negara Bagian Rakhine Di Myanmar. https://www.amnesty.org, [Diakses pada 28 Maret 2018].

Apriyanti, Devi. (2014). "Reformasi Politik dan Ekonomi di Myanmar Pada Masa Pemerintahan Presiden U Thein Sein (2011-2013)." Jurnal Online Mahasiswa (JOM) Fisip Vol. 1, No. 2, (Oktober 2014). https://jom.unri.ac.id, [Diakses pada 28 Maret 2018].

Berg, John Richard. (2016). "Insurgents to Presidents: Contemporary Civil-Military Relations in Brazil, El Salvador, and Uruguay." Thesis, Monterey, California: Naval Postgraduate School. https://calhoun.nps.edu [Diakses pada 07 April 2018]
Budiardjo, Miriam. (2001). Dasar-dasar Ilmu Politik. Jakarta: PT. Gramedia Pustaka Utama.

Egreteau, Renaud (2017). Parliamentary Development in Myanmar - An Overview of the Union Parliament, 2011-2016. Yangon: The Asia Foundation, https://reliebweb.int [Diakses pada 28 Maret 2018].

Kristiadi, J. (2001). "Profesionalisme TNI di Tengah Transisi Politik". Jurnal Antropologi Universitas Indonesia. http://journal.ui.ac.id [Diakses pada 07 April 2018].

Lunn, Jon \& Harari, Daniel. (2018). "Burma: January 2018 Update.” Briefing Paper, No. 7901, 9 (January 2018). http://www.parliament.uk/commonslibrary [Diakses pada 07 April 2018].

Muslina. (2016). "Upaya UNDP (United Nations Development Programme) Dalam Memajukan Demokrasi Di Myanmar." Jurnal Online Mahasiswa (JOM) FISIP, Vol. 3, No. 2, (Oktober 2016). https://jom.unri.ac.id [Diakses pada 28 Maret 2018]

Mendoza, Laura Baron. (2017). "The War Report 2017 - Myanmar: A Battle For Recognition." Research of Geneva Academy, Academy of International Humanitarian Law and Human Rights. https://www.geneva-academy.ch [Diakses pada 28 Maret 2018].

Myoe, Maung Aung. (2017). "Emerging Pattern Of Civil-Military Relations In Myanmar", Southeast Asian Affairs, (hlm. 259-270). https://www.researchgate.net [Diakses pada 28 Maret 2018].

Pujayanti, Adirini. (2017). "Indonesia dan Tragedi Kemanusiaan Rohingya". 
Majalah Info Singkat Hubungan Internasional, Vol. 9, No. 17, September 2017. www.puslit.dpr.go.id [Diakses pada 28 Maret 2018].

Raco, J.R. (2010). Metode Penelitian Kualitatif Jenis, Karakteristik, dan Keunggulannya. Jakarta: PT. Gramedia Widiasarana Indonesia.

Revolusi, Alfi et.al. (2013). "Faktor-faktor Penyebab Konflik Etnis Rakhine dan Rohingya di Myanmar Tahun 2012”. Artikel Ilmiah Hasil Penelitian Mahasiswa Universitas Jember. http://repository.unej.ac.id [Diakses pada 28 Maret 2018].

RFA (Radio Free Asia). (2017). "Myanmar Military Chief Defends Crackdown Against Rohingya in Rakhine State", www.rfa.org [Diakses pada 29 Maret 2018].

Schiff, Rebecca L. (2009). The Military and Domestic Politics: A Concordance Theory of Civil-Military Relations. New York: Routledge.

Siddiqui, Usaid. (2017). "The Rohingya: The Latest Massacre in a Violence-Filled History." Al Jazeera Centre for Studies. http://studies.aljazeera.net [Diakses pada 29 Maret 2018].

Sohel, Md. Salman. (2017). "The Rohingya Crisis in Myanmar: Origin and Emergence." Saudi Journal of Humanities and Social Sciences, Vol. 2, No. 11A. http://scholarsmepub.com, [Diakses pada 29 Maret 2018].

Stokke, Kristian., Vakulchuk, Roman \& Øverland, Indra. (2018). "Myanmar: A Political Economy Analysis". Oslo: Norwegian Institute of International Affairs, www.nupi.no [Diakses pada 29 Maret 2018].
Thontowi, Jawahir. (2013). "Perlakuan Pemerintah Myanmar terhadap Minoritas Muslim Rohingya Perspektif Sejarah dan Hukum Internasional". Jurnal Pandecta, Vol. 8, No. 1, (Januari 2013). http://journal.unnes.ac.id [Diakses pada 29 Maret 2018].

Thuzar, Moe. (2017). "Understanding Democracy, Security, and Change in Post-2015 Myanmar." The Journal of Asia Studies Vol. 22, No. 1. http://aas2.asian-studies.org [Diakses pada 28 Maret 2018].

Waluyo, Tri Joko. (2013). "Konflik Tak Seimbang Etnis Rohingya dan Etnis Rakhine di Myanmar. Jurnal Transnasional, Vol. 4, No. 2. https://ejournal.unri.ac.id [Diakses pada 28 Maret 2018]. 